\title{
Direct phototransformation of aromatic pesticides in aqueous solution
}

\author{
P. Boule, ${ }^{1, \dagger}$ L. Meunier, ${ }^{1}$ F. Bonnemoy, ${ }^{2}$ A. Boulkamh, ${ }^{3}$ \\ A. Zertal, ${ }^{3}$ and B. Lavedrine ${ }^{1}$ \\ ${ }^{1}$ Laboratoire de Photochimie Moléculaire et Macromoléculaire, Université Blaise Pascal - CNRS UMR 6505 \\ (Clermont-Ferrand) F - 63177 Aubière cedex France \\ ${ }^{2}$ Laboratoire de Biologie des Protistes, Université Blaise Pascal - CNRS UMR 6023 \\ (Clermont-Ferrand) F - 63177 Aubière cedex France \\ ${ }^{3}$ Laboratoire des Sciences et Technologies de l'Environnement, Université Mentouri, 25000 Constantine Algeria
}

\begin{abstract}
The photochemical behaviour of many aromatic pesticides (mainly herbicides) are compared and the main reactions are separated in three different classes: 1- reactions involving carbon-halogen bond; 2 other reactions involving the aromatic ring; 3 - reactions of the aliphatic moiety. It appears that the nature of the substituents and their relative positions on the ring play a major role in the orientation of the reaction. The molecular and ionic forms of ionisable molecules may have different photochemical behaviour. A wavelength effect is observed with some compounds. The case of mecoprop [2-(4-chloro-2-methylphenoxy)-propanoic acid] is presented as an example.

The irradiation of herbicides in aqueous solution may lead to the formation of photochemical intermediates more toxic to microorganisms than the initial substrate.
\end{abstract}

\section{INTRODUCTION}

When a pesticide is spread in the environment, only a low percentage of it reaches its target. Most of it remains on soil, on plants, or is washed out in natural waters. When the biodegradability is slow, as is often the case with halogenoaromatic derivatives, the direct or induced photodegradation may play a significant role in its elimination. The present study focuses on the direct phototransformation of aromatic derivatives. Its aim is to classify the main reactions into different groups and to examine the influence of the nature and position of substituents on the orientation of the reaction in order to get insight into and to bring out some rules for the chemical behaviour of common herbicides. Where relevant the influence of $\mathrm{pH}$ and irradiation wavelength is pointed out. Another aspect of this work is to study the influence of irradiation on the toxicity of solutions.

Before presenting the main reactions observed with aromatic pesticides, it is useful to have a rapid flash back on the phototransformation of halogenophenols and halogenoanilines. The photochemical behaviour of halogenophenols is summarized in Scheme 1. The orientation of the reaction is not significantly influenced by the nature of halogen $(\mathrm{Cl}, \mathrm{F}$ or $\mathrm{Br})$, but it is highly dependent on the position of the halogen on the ring. With 3-halogenophenols photohydrolysis is almost quantitative [1, 2]. It is not influenced by oxygen and it may be observed even in very acidic solution $(\mathrm{pH} \leq 1)[1]$.

${ }^{\dagger}$ E-mail: pierre.boule@univ-bpclermont.fr
The photochemical behaviour of 2-halogenophenols is more specific with the anionic form and leads mainly to the formation of cyclopentadiene carboxylic acids. It is also more efficient, displaying high quantum yield of disappearance (0.30 in the case of 2-chlorophenolate) [1]. With the molecular form the quantum yield of disappearance is about 10 times lower and photohydrolysis competes with photocontraction of the ring.

The phototransformation of 4-halogenophenols is more complex [1, 3]. It was really understood when the initial formation of a carbene was experimentally proved by Grabner et al. [4] and confirmed by Durand et al. [5]. In the presence of oxygen the carbene is oxidized into $p$-benzoquinone. In diluted deoxygenated solution it reacts with water leading to hydroquinone while in relatively concentrated solution $\left(\geq 10^{-3} \mathrm{M}\right)$ it reacts mainly with another molecule of the substrate with formation of 5-halogeno-2,4'-dihydroxybiphenyl. (Scheme 1).

Similar influence of the location of the halogen in the ring is reported in the phototransformation of halogenoanilines (Scheme 2). Photohydrolysis is the main initial reaction with 3 -halogenated derivatives $[6,7]$. In the case of 2-halogenated compounds photohydrolysis competes with photocontraction of the ring. This photocontraction leads to cyclopenta-1,3-diene-1carbonitrile [8]. With 4-halogenoanilines the first step is the formation of a cationic carbene [9]. According to the conditions it leads to the formation of 4-aminophenol, aniline, diphenylamine derivatives or substituted biphenyls. 
<smiles>[X]c1cccc(O)c1</smiles><smiles>[X]c1ccccc1O</smiles><smiles>[X]c1ccccc1[O-]</smiles><smiles>[X]c1ccc(O)cc1</smiles><smiles>[X]c1ccc(O)c(-c2ccc(O)cc2)c1</smiles><smiles>O=C1C=CC(=O)C=C1</smiles>

Scheme 1. Photochemical behaviour of halogenophenols $(\mathrm{X}=\mathrm{Cl}, \mathrm{F}, \mathrm{Br})$.

\section{MATERIALS AND METHODS}

2.1. Substrates. The following compounds were studied:

- phenylureas and halogenated derivatives

fenuron<smiles>CN(C)C(=O)Nc1ccccc1</smiles>
isoproturon<smiles>CC(C)c1ccc(NC(=O)N(C)C)cc1</smiles>

chlorotoluron<smiles>Cc1ccc(NC(=O)N(C)C)cc1Cl</smiles>
metoxuron<smiles>COc1ccc(NC(=O)N(C)C)cc1Cl</smiles>

diuron linuron

metobromuron<smiles>CON(C)C(=O)Nc1ccc(Br)cc1</smiles>

monuron<smiles>CN(C)C(=O)Nc1ccc(Cl)cc1</smiles><smiles>CN(C)C(=O)Nc1ccc(Cl)c(Cl)c1</smiles>

chlorbromuron<smiles>CON(C)C(=O)Nc1ccc(Cl)c(Cl)c1</smiles><smiles>CON(C)C(=O)Nc1ccc(Br)c(Cl)c1</smiles> 
- chlorophenylcarbamates<smiles>[R]C(=O)ONc1cccc(Cl)c1</smiles>

(chlorpropham $\mathrm{R}=\mathrm{iPr}$

chlorbufam $\left.\mathrm{R}=-\mathrm{CH}\left(\mathrm{CH}_{3}\right)-\mathrm{C} \equiv \mathrm{CN}\right)$

- chlorophenoxyacetic acids<smiles>[R]c1cc(Cl)ccc1OC([R2])C(=O)O</smiles>

$\left(\mathrm{MCPA} \mathrm{R} \mathrm{R}_{1}=\mathrm{CH}_{3}, \mathrm{R}_{2}=\mathrm{H}\right.$

mecoprop $\mathrm{R}_{1}=\mathrm{CH}_{3}, \mathrm{R}_{2}=\mathrm{CH}_{3}$

dichlorprop $\mathrm{R}_{1}=\mathrm{Cl}, \mathrm{R}_{2}=\mathrm{CH}_{3}$ )

- other halogenoaromatic derivatives<smiles>N#Cc1cc(Br)c(O)c(Br)c1</smiles>

1,4-dichlorobenzene<smiles>Clc1ccc(Cl)cc1</smiles>

propanil<smiles>CCOC(=O)Nc1ccc(Cl)c(Cl)c1</smiles>

- unhalogenated compounds

o-phenylphenol

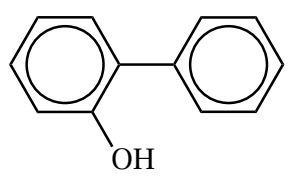<smiles>CCCCCCCCCCCCC(=O)Oc1cccc2ccccc12</smiles>

All of these compounds are used as herbicides, except $o$-phenylphenol which is a fungicide, and 1,4dichlorobenzene, a commonly used insects repellant.
2.2. Irradiations. Solutions were irradiated at $254 \mathrm{~nm}$ using low pressure mercury lamps, between 290 and $350 \mathrm{~nm}$ with fluorescent lamps "Duke Sunlamp GL20", at $365 \mathrm{~nm}$ with lamps "Mazda" MAW 125W-T or in sunlight. Lamps MAW 125W-T consist of a medium pressure mercury lamp surrounded by a filtering glass transmitting mainly the line at $365 \mathrm{~nm}$. However a low percentage of light is emitted at 313 and $334 \mathrm{~nm}$.

2.3. Analysis. Most often solutions were analysed by HPLC on column $\mathrm{C}_{18}$ with photodiode array detector using a water-methanol mixture as the eluent. The main photoproducts were identified by means of mass spectrometry and ${ }^{1} \mathrm{H}$ NMR.

2.4. Evaluation of toxicity to microorganisms. Toxicity was evaluated with the Microtox ${ }^{\circledR}$ test whereby tolerance towards toxicant of the fluorescent marine bacterium Vibrio Fischeri is examined. Toxicity is quantified by $\mathrm{EC}_{50}$ which is the concentration inhibiting $50 \%$ of the fluorescence after a 5,15 or $30 \mathrm{~min}$ exposure time. The toxicity scales obtained with this bacterium and with other microorganisms are not necessarily identical.

\section{REACTIONS OBSERVED IN THE PHOTOTRANSFORMATION OF AROMATIC PESTICIDES}

These reactions can be separated in three different classes: reactions involving carbon-halogen bond (in the case of halogenated compounds), other reactions involving the aromatic ring and reactions of the aliphatic moiety.

\subsection{Reactions involving carbon-halogen bond.}

\subsubsection{Photohydrolysis.}

Photohydrolysis is the reaction most commonly encountered in the phototransformation of halogenated aromatic compounds. It is the substitution of a halogen atom by $\mathrm{OH}$ involving a molecule of water. This reaction is almost quantitative with meta-halogenated phenylureas such as chlorotoluron [10] and metoxuron [11], and with meta-halogenated phenylcarbamates (chlorpropham [6], chlorbufam [10]). It is also the main pathway with many other herbicides such as bromoxynil and chlorophenoxyacetic acids in the anionic form. This reaction is not influenced by oxygen. In some cases it occurs even in very acidic solution $(\mathrm{pH} \leq 1)$ and it is more efficient with fluorinated compounds than with chlorinated ones. From these observations it is deduced that the reaction results from a heterolytic mechanism, involving a molecule of water. It is most probably a concerted mechanism since no carbocation was observed in laser flash photolysis. It is thought that a molecule of water reacts with the carbon-halogen bond polarized 
<smiles>[X]c1cccc(N)c1</smiles><smiles>[X]c1ccccc1N</smiles>

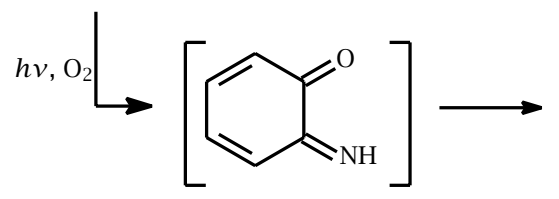<smiles>Nc1cc2nc3ccccc3oc-2cc1=O</smiles>

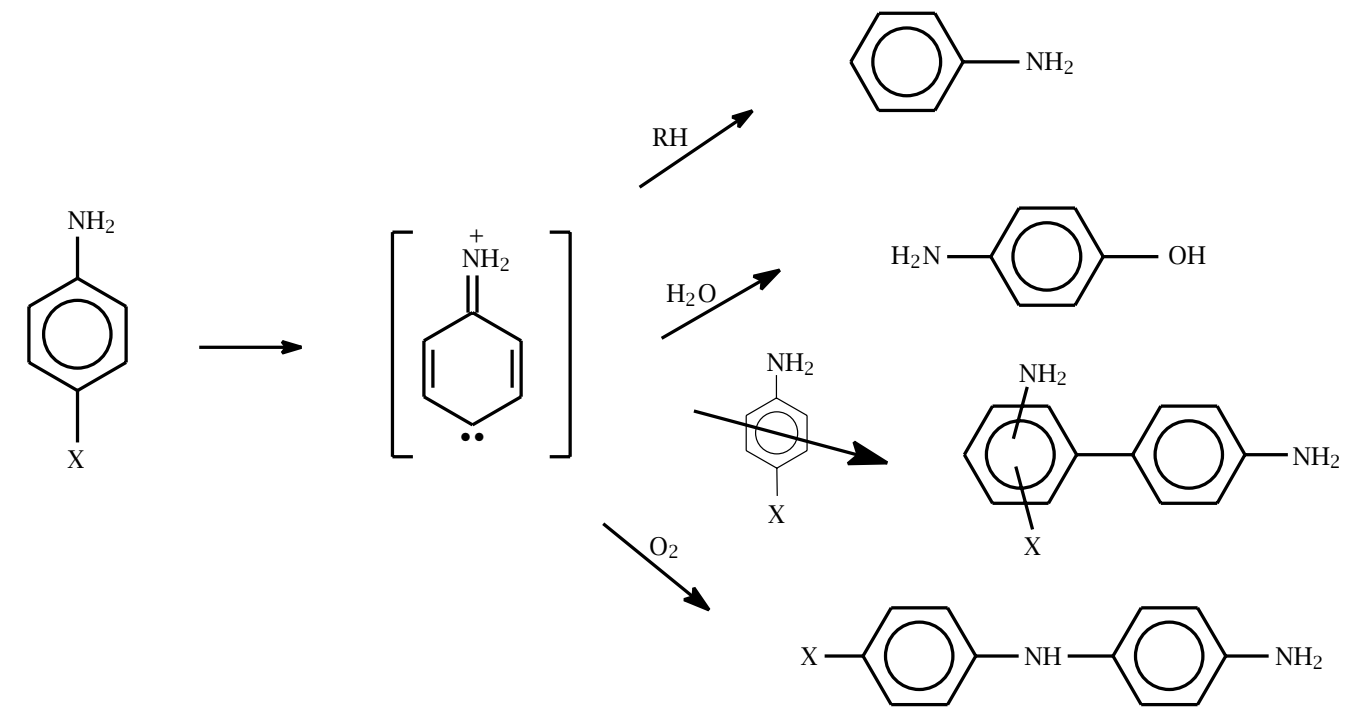

Scheme 2. Photochemical behaviour of halogenoanilines $(\mathrm{X}=\mathrm{Cl}, \mathrm{F}, \mathrm{Br})$.

in the excited state (Scheme 3). The fact that the photohydrolysis of halogenophenols can be sensitized [2] proves that it does occur from the triplet excited state, but it does not prove that it only occurs from this state.

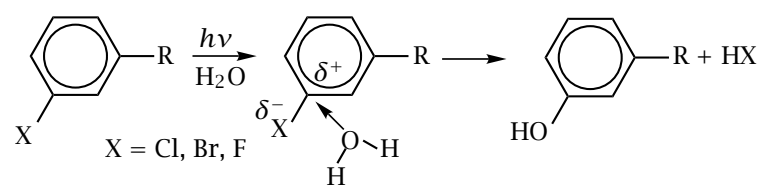

Scheme 3.
With dihalogenated aromatic compounds photohydrolysis may occur on either of the two sites, but in some cases the irradiation wavelength affects the orientation of the reaction. For example when diuron [3(3,4-dichlorophenyl)-1,1-dimethylurea] is irradiated at $254 \mathrm{~nm}$ photohydrolysis in meta position accounts for ca. $90 \%$ of the transformation, whereas in sunlight or in near UV irradiation the product of para-hydroxylation is the main photoproduct [12]. This wavelength effect is related to the presence of $\mathrm{NH}-\mathrm{CO}$ group since it is also reported with other halogenophenylureas [13] and with propanil [N-(3,4-dichlorophenyl)propanamide], 


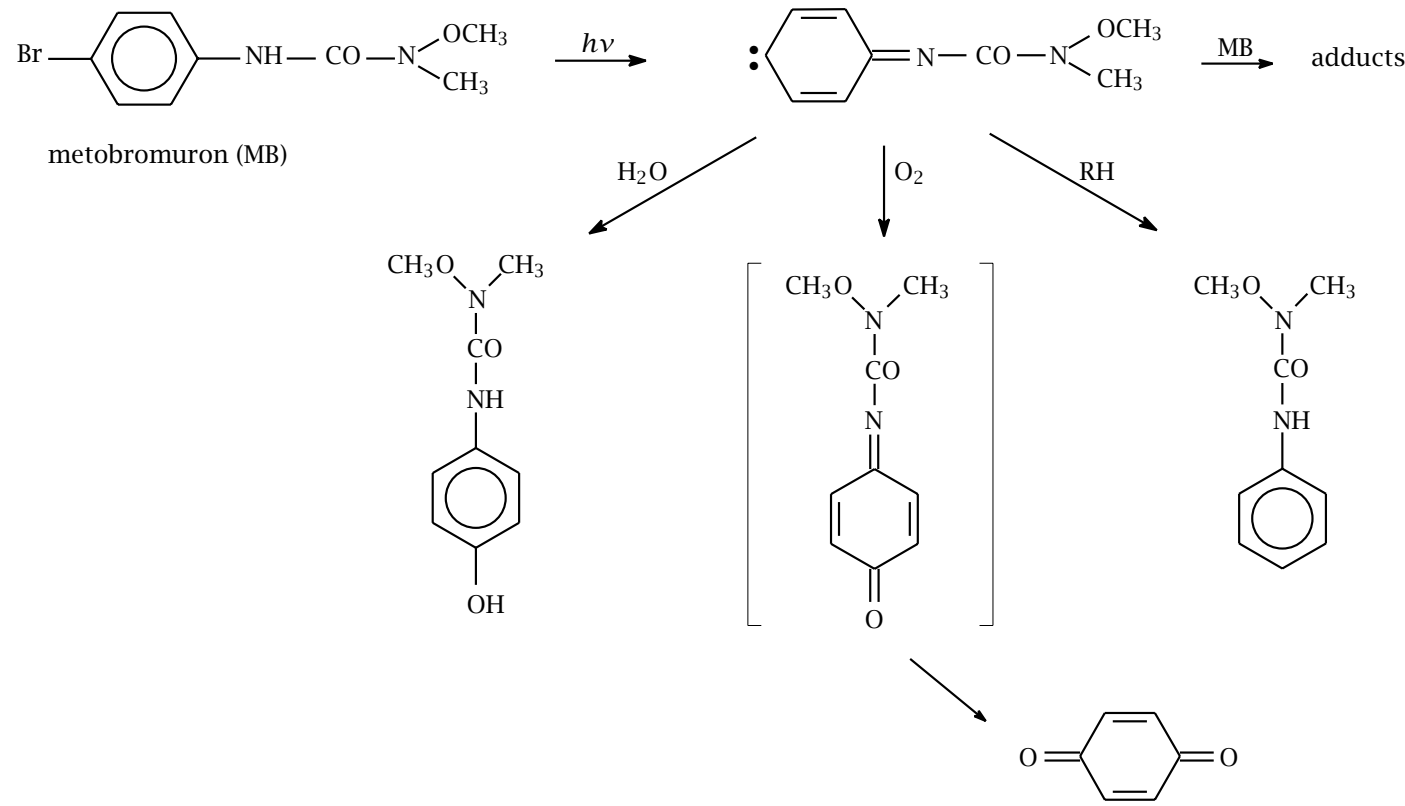

Scheme 4. Phototransformation of metobromuron involving the intermediate formation of a carbene.

but it was not observed with N-methylated diuron [14]. It is suggested, but not definitively established, that the formation of the $p$-hydroxylated derivative involves the minor presence of enolic form $(\mathrm{N}=\mathrm{COH})$ from which $p$-hydroxylation should be much easier. The enolic form is not possible for N-methylated compounds.

\subsubsection{Reactions resulting from the intermediate formation of a carbene.}

With $p$-halogenated phenols and anilines it is experimentally proved that the first step of the reaction is the formation of a carbene. The same type of reaction is observed with metobromuron [3-(4-bromophenyl)1-methoxy-1-methylurea] where carbene formation accounts for about $45 \%$ of the sum of reactions of metobromuron [15]. This carbene can then be hydrolysed that explains the formation of the $p$-hydroxylated derivative reported by Rosen, Strusz, Nick and Schöler $[16,17]$. In the presence of oxygen, the main transformation pathway of the carbene is its oxidation into $p$-benzoquinone through the intermediate formation of an unstable quinone-imine [15]. The carbene may also be reduced (in the presence of H-donor substances), or, in more concentrated solutions, lead to the formation of adducts. (The formation of adducts was reported by Rosen and Strusz [16]). This complex photochemical reactivity deriving from the initial formation of a carbene is presented in Scheme 4, but, as it will be mentioned later in this paper, the phototransformation of metobromuron also involves another pathway.

\subsubsection{Photoreduction of carbon-halogen bond.}

Photoreduction is generally a minor pathway in pure water, but it is the major reaction in alcohols. For example monuron [3-(4-chlorophenyl)-1,1-dimethylurea] irradiated at $254 \mathrm{~nm}$ in methanol is phototransformed into fenuron [3-phenyl-1,1-dimethylurea] [18], and diuron is reduced in $p$-position [19] (Scheme 5). It may be noted that in contrast with photohydrolysis photoreduction is easier in para-position than in meta-position.


monuron

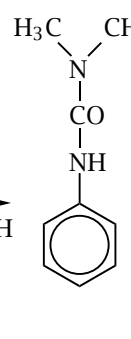
fenuron<smiles>CN(C)C(=O)Nc1ccc(Cl)c(Cl)c1</smiles>

diuron
Scheme 5 .

\subsection{Reactions concerning the aromatic ring.}

\subsubsection{Photorearrangement.}

Photorearrangement is reported with many aromatic herbicides namely chlorophenoxyacetic acids [20, 21], mecoprop [22], fenuron [23], isoproturon [10], 2-naphtoxyacetic acid [20] and napropamide [24]. Fenuron and napropamide are given as examples in Scheme 6: 


$$
\text { 等 }
$$
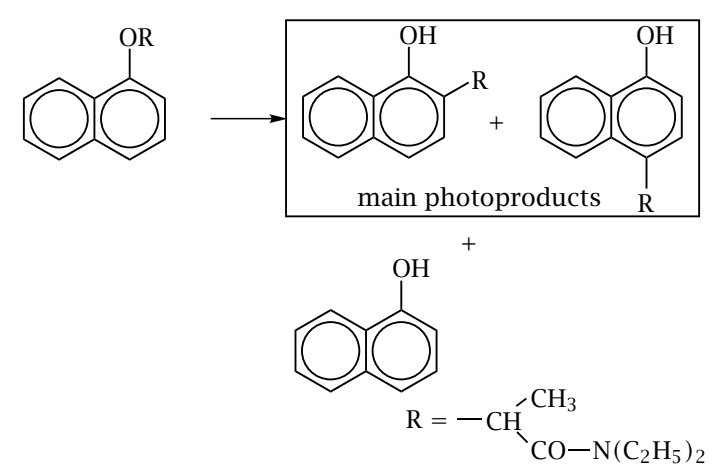

Scheme 6 .

It is generally admitted that this reaction involves a radical mechanism, the aliphatic radical released reacting on the positions of highest spin density i.e. in ortho and para positions with respect to $\mathrm{OH}$ or $\mathrm{NH}_{2}$ group:

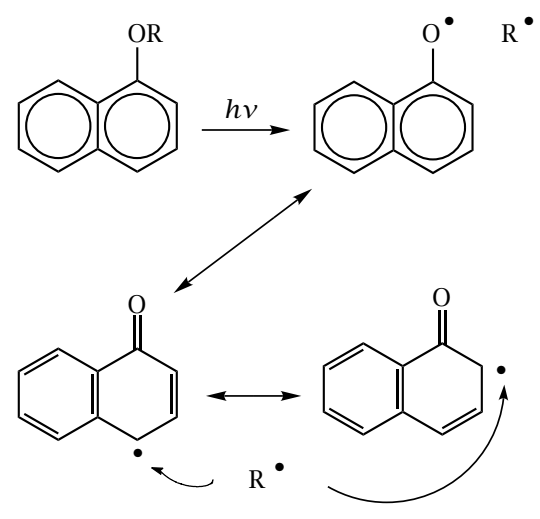

Scheme 7.

Only one isomer is formed when isoproturon is irradiated at $254 \mathrm{~nm}$ since para position is substituted, but no rearrangement is observed when a solution is irradiated at $\lambda \geq 275 \mathrm{~nm}$ [10]:

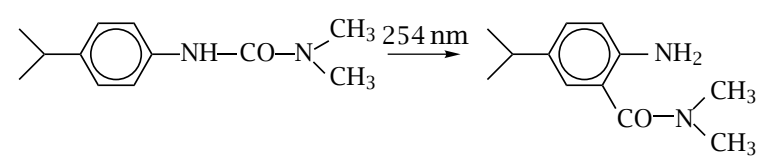

Scheme 8.

This wavelength effect is probably due to the fact that photorearrangement results from the excitation in a $\pi \pi^{*}$ band as it was suggested by Shizuka and Tanaka [25].

\subsubsection{Photooxidation.}

Photooxidation is more common with phenolic derivatives than with halogenated aromatic compounds because of the electro-donating influence of $\mathrm{OH}$ group and the withdrawing effect of halogen atoms. For example phenylhydroquinone, phenylbenzoquinone and acids resulting from ring opening are the main photoproducts initially formed when 2-phenylphenol (a well known fungicide) is irradiated in aqueous solution [26, 27]:

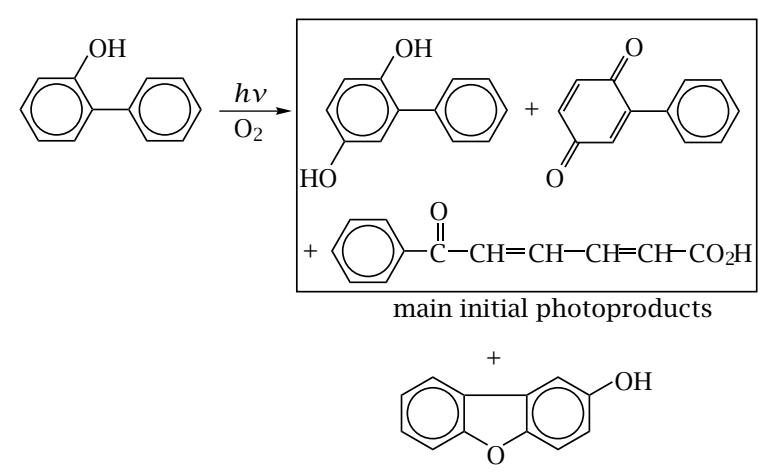

Scheme 9.

The first step of the reaction is an electron or hydrogen transfer from 2-phenylphenol to oxygen followed by the attack of the hydroperoxyl radical formed in para position of the phenolic function or in the ring junction:
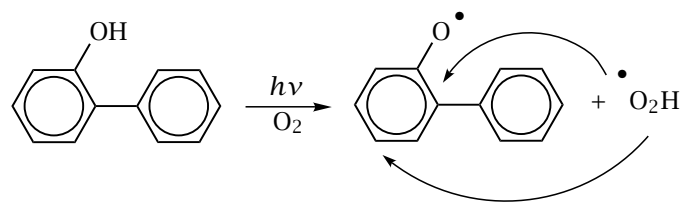

Scheme 10

\subsubsection{Photocyclisation.}

The formation of 2-hydroxydibenzofuran is also observed in the phototransformation of 2-phenylphenol. In fact this reaction does not result from the direct excitation of 2-phenylphenol, but from the excitation of phenylbenzoquinone formed in a first step. This reaction, only observed in polar solvents, proceeds from the triplet excited state of phenylbenzoquinone [28, 29]: 


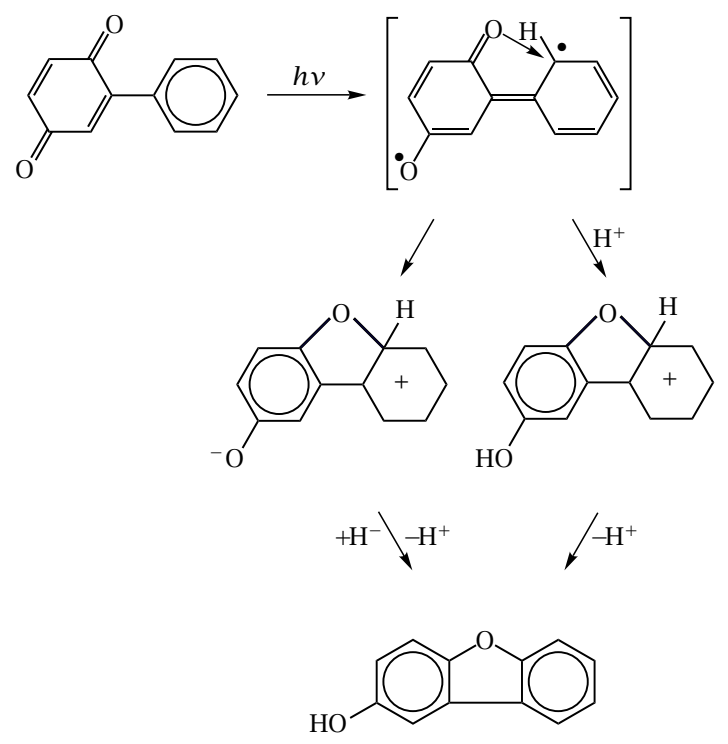

Scheme 11 .

The formation of 2-hydroxydibenzofuran when 1,4dichlorobenzene is irradiated in deoxygenated aqueous solution is more surprising [30], but it can be noted that conditions of its formation do not correspond to environmental conditions. It probably arises from the intermediate formation of hydroquinone and a hydroxychlorobiphenyl derivative.

\subsection{Reactions involving the aliphatic moiety.}

\subsubsection{Demethoxylation of methoxylated phenylureas.}

$\mathrm{N}$-methoxylated phenylureas such as metobromuron, linuron and chlorbromuron are commonly used as herbicides. One of the main pathways of phototransformation is the elimination of methoxy group released as formaldehyde $[13,15]$ :<smiles>[R2]c1ccc(NNC(=O)N(C)OC)cc1[R2]</smiles><smiles>[R2]c1cc(NNC(=O)NC)ccc1[R17]OC</smiles>

$$
\begin{array}{ll}
\text { metobromuron } & \mathrm{R}_{1}=\mathrm{Br}, \mathrm{R}_{2}=\mathrm{H} \\
\text { linuron } & \mathrm{R}_{1}=\mathrm{R}_{2}=\mathrm{Cl} \\
\text { chlorbromuron } & \mathrm{R}_{1}=\mathrm{Br}, \mathrm{R}_{2}=\mathrm{Cl}
\end{array}
$$

Scheme 12.

Demethylation and oxidation of methyl group also occur, but they are minor pathways in aqueous solution.

\subsubsection{Ether bond scission.}

Ether bond scission is reported with various herbicides such as napropamide [24], chlorophenoxyacetic acids [20, 21, 31] and chlorophenoxypropanoic acids [22]. It leads to the formation of corresponding phenols:<smiles>[R1]c1cc(Cl)ccc1OC([R2])C(=O)OCCCC</smiles>

$$
\text { 4-chlorophenoxyacetic acid } \quad \mathrm{R}_{1}=\mathrm{R}_{2}=\mathrm{H}
$$$$
\text { 2,4-D : } \mathrm{R}_{1}=\mathrm{Cl} \quad \mathrm{R}_{2}=\mathrm{H}
$$$$
\text { MCPA : } \mathrm{R}_{1}=\mathrm{CH}_{3} \quad \mathrm{R}_{2}=\mathrm{H}
$$$$
\text { mecoprop : } \mathrm{R}_{1}=\mathrm{R}_{2}=\mathrm{CH}_{3}
$$$$
\text { dichlorprop : } \mathrm{R}_{1}=\mathrm{Cl} \quad \mathrm{R}_{2}=\mathrm{CH}_{3}
$$

Scheme 13.

This reaction may result from two distinct processes: homolysis of the excited molecule and induced photooxidation. The formation of rearrangement products provides evidence for the occurrence of direct homolysis. The formation of the same products by irradiation of solutions of MCPA or mecoprop containing $\mathrm{TiO}_{2}$, nitrite ions, ferric salts or quinonic derivatives at wavelengths where direct photolysis is not possible gives support for the occurrence of induced photooxydation. As it will be presented in the next section the involvement of these two pathways can explain the observed wavelength effect.

\subsection{Mecoprop: an example of complex mecha-} nism. In some cases the irradiation of a pesticide leads to the formation of one major product by one of the reactions described in Sections 3.1-3.3. Most often the photodegradation of a pesticide involves several pathways, in proportions depending on the conditions of irradiation. For example the photochemical behaviour of mecoprop, a systemic herbicide, depends on both $\mathrm{pH}$ and irradiation wavelength [22].<smiles>Cc1cc(O)ccc1OC(C)C(=O)O</smiles><smiles>Cc1ccccc1O</smiles><smiles>Cc1cc(Cl)cc(C(C)C(=O)O)c1O</smiles><smiles>Cc1cc(Cl)ccc1O</smiles><smiles>CC1=CC(=O)C=C(C(C)C(=O)O)C1=O</smiles>

Scheme 14.

The pKa of mecoprop [( \pm 2 -(4-chloro-2-methylphenoxy)propanoic acid] is 3.78 [32]. When the anionic 


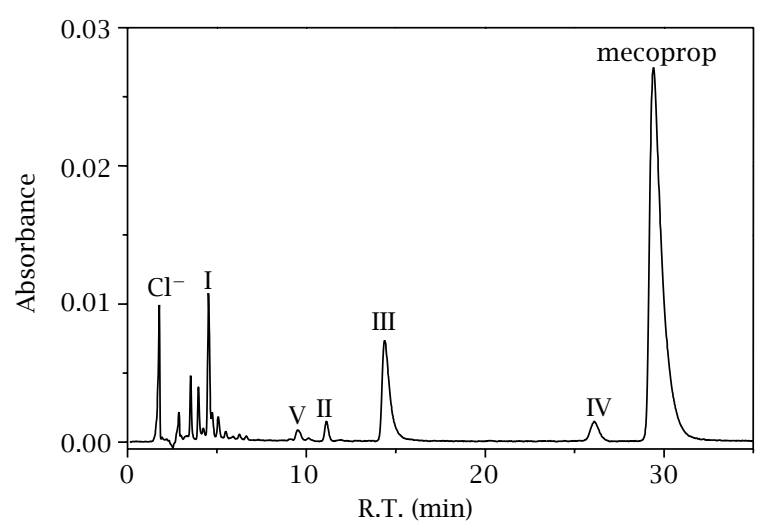

Figure 1. HPLC chromatogram of an air-saturated aqueous solution of mecoprop $5 \times 10^{-4} \mathrm{M}$, $\mathrm{pH}=2.15$, irradiated between 275 and $350 \mathrm{~nm}$. Conversion extent: about $41 \%$. Eluent : acidified water/acetonitrile.

form (at $\mathrm{pH}=5.5$ ) is irradiated at $\lambda \leq 350 \mathrm{~nm}$ photohydrolysis (formation of I) accounts for about $90 \%$ of the transformation. The formation of 2-methylphenol (II) is also reported, but it is a minor pathway. These photoproducts also appear when an aqueous solution is irradiated at $\mathrm{pH}=2.15$ in order to excite the molecular form (Products I and II on the chromatogram of Figure 1), but they only account for a low percentage of the transformation. The main product (III) results from a photorearrangement, but some other products are detected, namely 4-chloro-2-methylphenol (IV) resulting from ether bond scission and the substituted quinone (V). In contrast, when an unbuffered solution of mecoprop is irradiated in sunlight or in near UV light (lamps with a main line at $365 \mathrm{~nm}$ and minor emission at 313 and $334 \mathrm{~nm}$ ), the phototransformation is very slow and the main photoproduct is IV. With the molecular form, disappearance of mecoprop and formation of IV are reported to be self-accelerated [22]. IV is also the main product when oxidation of mecoprop is photoinduced by $\mathrm{TiO}_{2}$, nitrite ions, ferric salts or methylbenzoquinone. From these observations it is deduced that formation of IV in sunlight is mainly due to oxidation photoinduced by quinonic derivatives such as product $\mathrm{V}$ and methylbenzoquinone.

The main pathways in the phototransformation of mecoprop are presented on Scheme 15. Similar photochemical behaviour was observed with MCPA (4-chloro2-methylphenoxyacetic acid) [33]. It is worth noting that the degradation of MCPA may be photosensitized by riboflavin and that, in these conditions, 4-chloro-2methylphenol is the main product [34].

\subsection{Influence of irradiation on the toxicity of solu-}

tions. Another important aspect of the photochemical reaction of pesticides are the consequences that irradiation may have on the toxicity of solutions. The

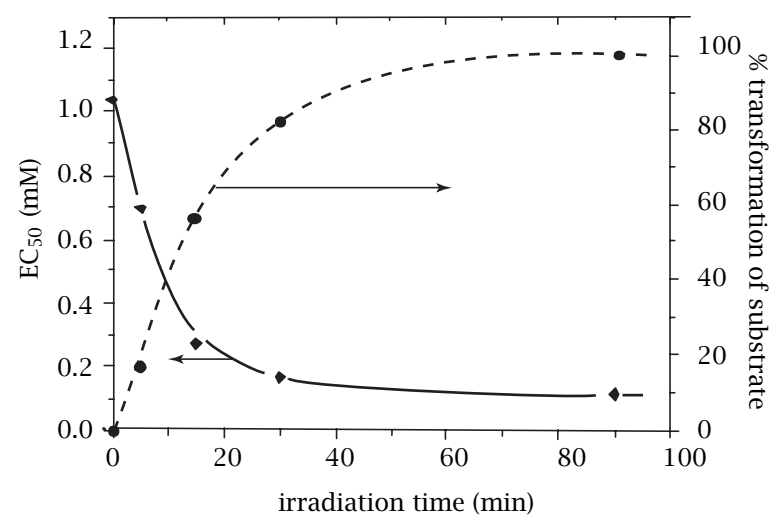

Figure 2. Influence of irradiation on metoxuron solutions toxicity (Microtox ${ }^{\circledR}$ test). Full line: value of $E C_{50}$; broken line: disappearance of substrate.

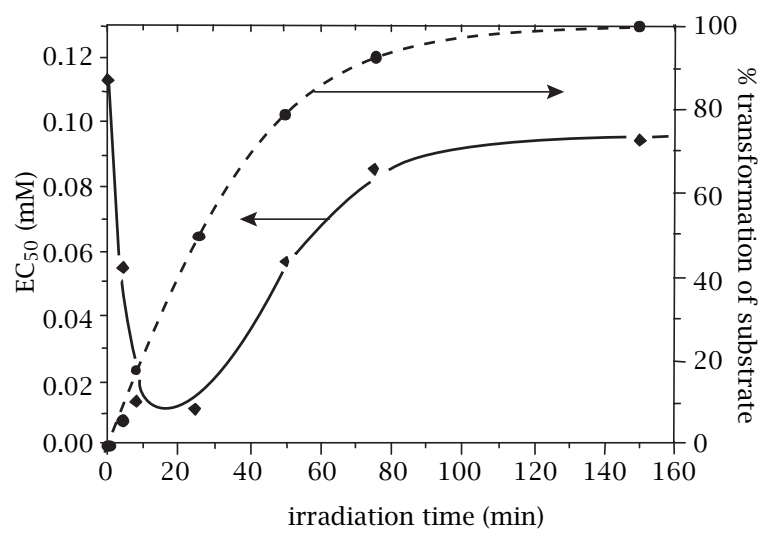

Figure 3. Influence of irradiation on metobromuron solutions toxicity (Microtox ${ }^{\circledR}$ test). Full line: value of $E C_{50}$; broken line: disappearance of substrate.

toxicity to the fluorescent marine bacterium Vibrio fischeri was evaluated by determining $\mathrm{EC}_{50}$ which is the concentration of pesticide inhibiting $50 \%$ of the bacterium fluorescence (Microtox ${ }^{\circledR}$ Test). A decrease of $\mathrm{EC}_{50}$ corresponds to an increase of toxicity.

Two examples are given in Figures 2 and 3 for metoxuron and metobromuron respectively. In both cases $\mathrm{EC}_{50}$ initially decreases which means that irradiation increases toxicity to Vibrio fischeri. With metoxuron the formation of the hydroxylated product is almost quantitative and it is likely that 3-(3-hydroxy-4methoxyphenyl)-1,1-dimethylurea is more toxic than metoxuron. With metobromuron the reaction is more complex. After an initial rapid increase toxicity decreases. It can be deduced that the increase of toxicity is mainly due to an intermediate product that does not accumulate in the solution. Toxicities are not necessarily in the same order with Vibrio fischeri and with other microorganisms. 


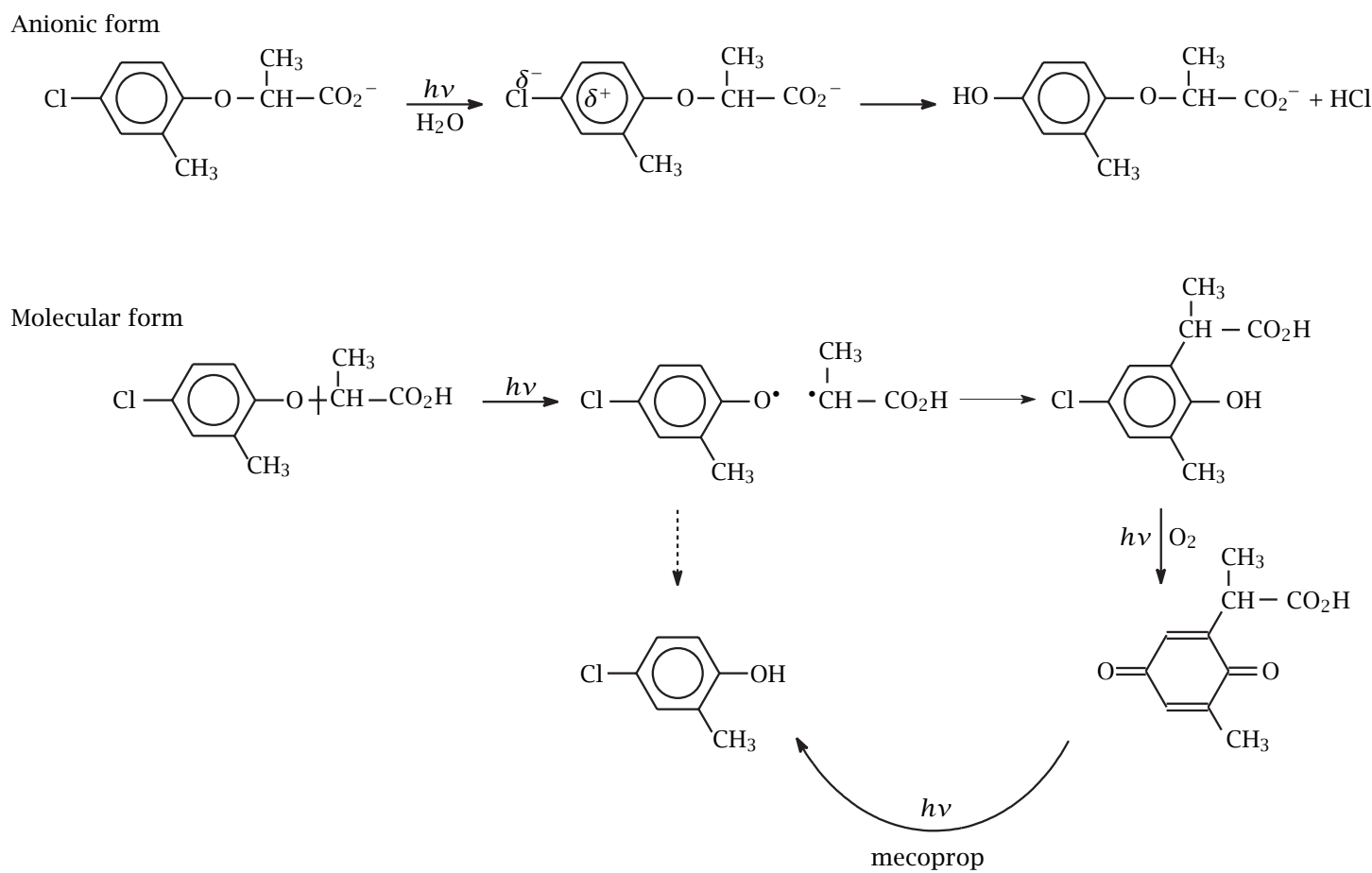

Scheme 15. Main pathways in the phototransformation of mecoprop.

Herbicides users have to be aware that irradiation may induce an increase of toxicity. However for long term sunlight exposure photoproducts initially formed may undergo further degradation and do not necessarily accumulate in water. Such a control would be useful.

\section{CONCLUSIONS}

Many reactions may occur in the phototransformation of aromatic pesticides. The orientation of the reaction depends on the nature of the aliphatic moiety and on the nature and position of substituents on the ring. The orientation of the reaction may also depend on $\mathrm{pH}$ (with ionisable molecules) and irradiation wavelength. The latter phenomenon may be due to the larger part taken by induced phototransformations at longer wavelengths. Consequently it is useful to study photochemical reactions in well defined laboratory conditions, but it is necessary to control that these reactions do really occur in environmental conditions.

The irradiation of pesticides may increase the toxicity of solutions and it is useful to control that photoproducts do not accumulate in water.

\section{References}

[1] P. Boule, C. Guyon, and J. Lemaire, Chemosphere 11 (1982), 1179.

[2] K. David-Oudjehani and P. Boule, New J. Chem. 19 (1995), 199.
[3] K. Oudjehani and P. Boule, J. Photochem. Photobiol. A: Chem. 68 (1992), 363.

[4] G. Grabner, C. Richard, and G. Köhler, J. Am. Chem. Soc. 116 (1994), 11470.

[5] A. P. Durand, R. G. Brown, D. Worrall, and F. Wilkinson, J. Photochem. Photobiol. A: Chem. 96 (1996), 35.

[6] B. David, M. Lhote, V. Faure, and P. Boule, Water Res. 32 (1998), 2451.

[7] K. Othmen, Thesis, Clermont-Ferrand (France), 1999.

[8] K. Othmen and P. Boule, J. Photochem. Photobiol. A: Chem. 136 (2000), 79.

[9] K. Othmen, P. Boule, B. Szczepanik, K. Rothiewicz, and G. Grabner, J. Phys. Chem. A 104 (2000), 9525.

[10] C. Tixier, L. Meunier, F. Bonnemoy, and P. Boule, Intern. J. Photoenergy 2 (2000), 1.

[11] A. Boulkamh, D. Harakat, T. Sehili, and P. Boule, Pest Manag. Sci., in press.

[12] J. Jirkovský, V. Faure, and P. Boule, Pestic. Sci. 50 (1997), 42.

[13] V. Faure and P. Boule, Pestic. Sci. 51 (1997), 413.

[14] V. Faure, Thesis, Clermont-Ferrand (France), 1996.

[15] A. Boulkamh, T. Sehili, and P. Boule, J. Photochem. Photobiol. A: Chem., in press.

[16] J. D. Rosen and R. F. Strusz, J. Agric. Food Chem. 16 (1968), 568.

[17] K. Nick and H. F. Schöler, Vom Wasser 86 (1996), 57. 
[18] P. H. Mazzochi and M. P. Rao, J. Agric. Food Chem. 20 (1972), 957.

[19] V. Faure and P. Boule, Toxicol. Environ. Chem. 63 (1997), 171.

[20] M. J. Climent and M. A. Miranda, J. Agric. Food Chem. 45 (1997), 1916.

[21] A. Zertal, T. Sehili, and P. Boule, Z. Phys. Chem. 213 (1999), 87.

[22] L. Meunier and P. Boule, Pest Manag. Sci. 56 (2000), 1077.

[23] J.-P. Aguer and C. Richard, Pestic. Sci. 46 (1996), 151.

[24] J.-P. Aguer, P. Boule, F. Bonnemoy, and J.-M. Chezal, Pestic. Sci. 54 (1998), 253.

[25] M. Shizuka and I. Tanaka, Bull. Chem. Soc. Japan 42 (1969), 909.

[26] A. Seffar, G. Dauphin, and P. Boule, Chemosphere 16 (1987), 1205.
[27] M. Sarakha, G. Dauphin, and P. Boule, Chemosphere 18 (1989), 1391.

[28] M. Sarakha, A. Rossi, G. Guyot, and P. Boule, C. R. Acad. Sci. Paris, série II, Vol. 307, 1988, p. 739.

[29] R. Bonneau, H. Moufid, and G. Guyot, New J. Chem. 15 (1991), 257.

[30] L. Meunier, J.-F. Pilichowski, and P. Boule, Can. J. Chem., in press.

[31] D. G. Crosby and H. O. Tutass, J. Agric. Food Chem. 14 (1966), 596.

[32] C. Tomlim, The Pesticide Manual, Crop Protection Publications, The Bath Press, $10^{\text {th }}$ ed. 1994, p. 646.

[33] A. Zertal, T. Sehili, and P. Boule, J. Photochem. Photobiol. A: Chem., in press.

[34] J. Soley, M. Vicente, P. Clapés, and S. Esplugas, Ind. Eng. Chem. Prod. Res. Dev. 25 (1986), 645. 


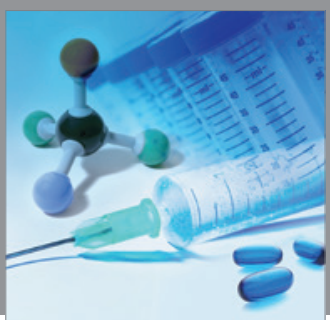

International Journal of

Medicinal Chemistry

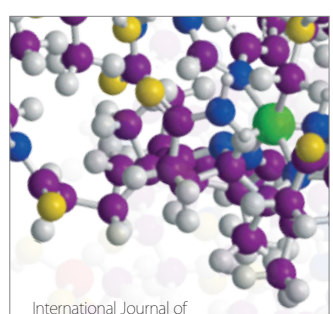

Carbohydrate Chemistry

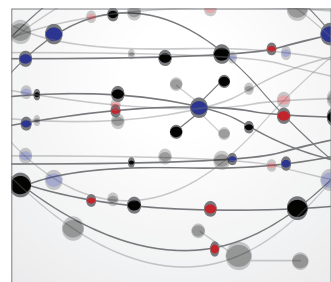

The Scientific World Journal
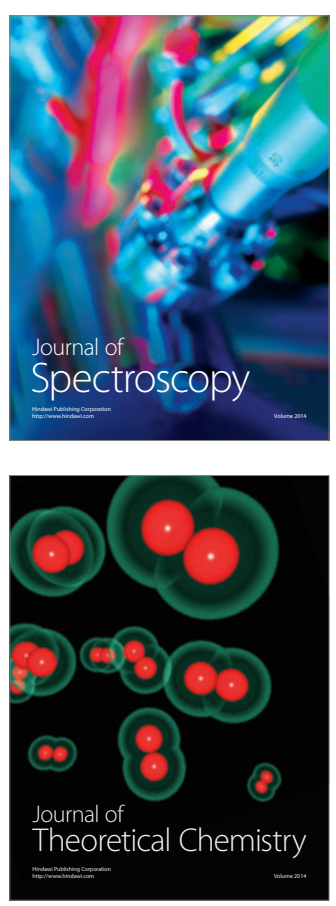
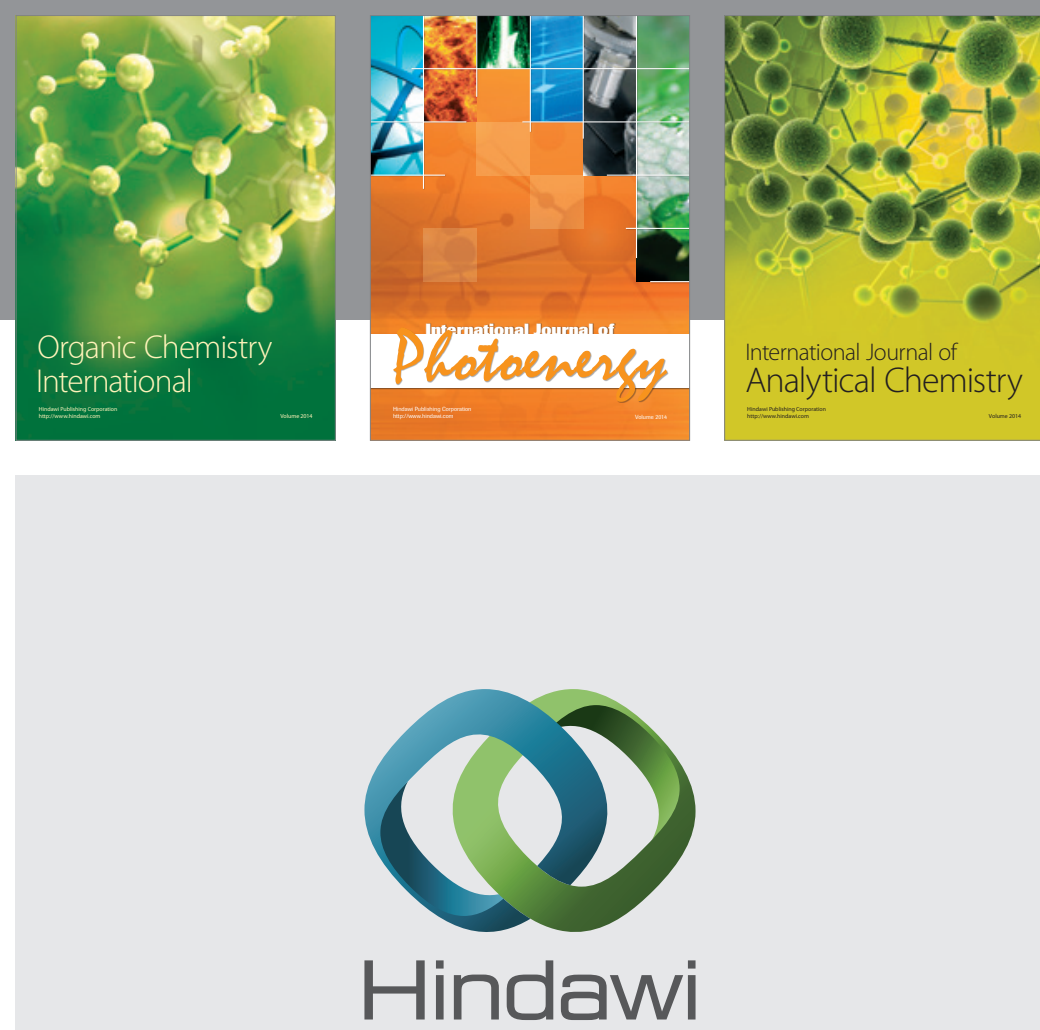

Submit your manuscripts at

http://www.hindawi.com
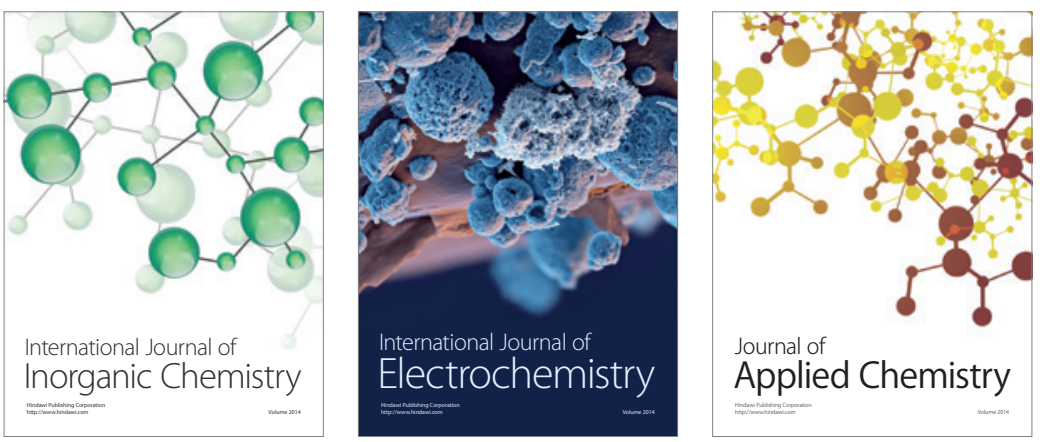

Journal of

Applied Chemistry
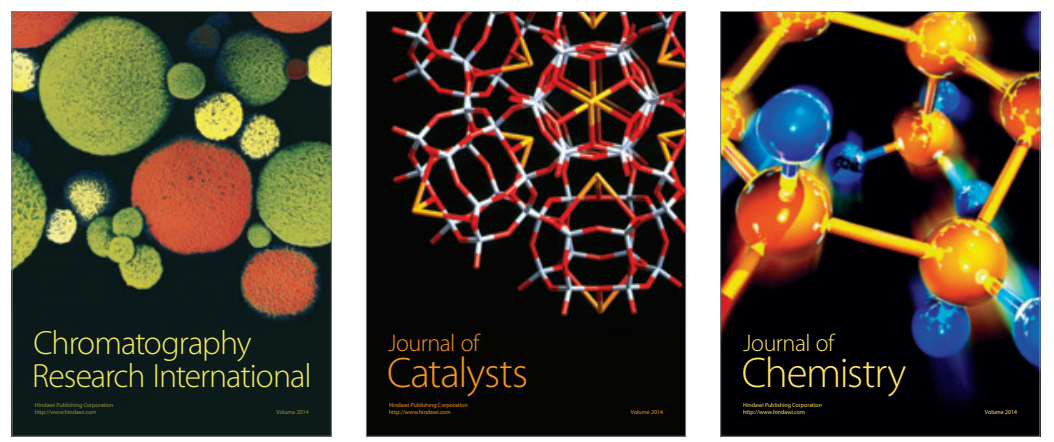
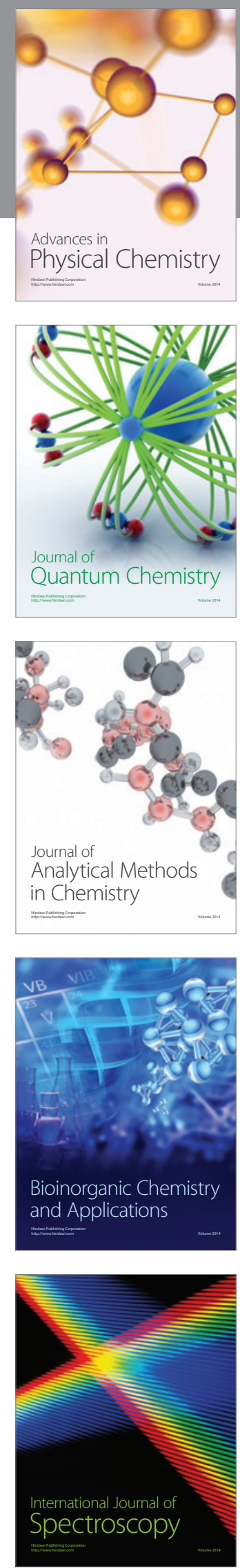